\title{
Recruitment implications of larval herring overwintering distributions in the Gulf of Maine, inferred using a new otolith technique
}

\author{
David W. Townsend ${ }^{1}$, Richard L. Radtke ${ }^{2}$, Melissa A. Morrison ${ }^{1}$, Scott D. Folsom ${ }^{2}$ \\ ${ }^{1}$ Bigelow Laboratory for Ocean Sciences, McKown Point, W. Boothbay Harbor, Maine 04575, USA \\ ${ }^{2}$ Hawaii Institute of Geophysics, University of Hawaii, Honolulu, Hawaii 96822, USA
}

\begin{abstract}
We have applied a Sr/Ca ratio technique of otolith analysis to reconstruct the temperature histories of fall-spawned herring larvae Clupea harengus L. captured in inshore waters of the Gulf of Maine, USA, in order to infer their overwintering distributions. Winter survival of herring larvae is believed to be a determinant of recruitment in the Gulf of Maine, though very little is known about this important phase in their life history. Shortly after hatching in coastal spawning areas, larvae congregate inshore along the Maine coast during fall (September to November). Following this abundance peak, inshore larval densities drop to very low levels in mid-winter (late December and January), before a second group of fall-spawned larvae appears inshore in spring (February through April), thus giving a bimodal abundance distribution with time. We have inferred the overwintering distributions of larvae captured in the spring in the Sheepscot River estuary, Maine, by analyzing changes in the concentrations ratios of strontium to calcium in the otoliths. These ratios vary as a function of temperature and thus act as a biological recorder of water temperatures experienced by an individual larva throughout its life history. Results suggest that the spring peak of herring larvae inshore represents larvae which overwintered offshore in the Gulf of Maine, implying that larvae which enter the inshore nursery areas in the fall do not survive.
\end{abstract}

\section{INTRODUCTION}

Atlantic herring Clupea harengus L. is commercially a very important species which has been fished heavily in the Northwest Atlantic for centuries. Unfortunately, the fishery is subject to extreme year-to-year fluctuations in year-class strength (Sindermann 1979). Although it has been the subject of intense study in the Gulf of Maine, our knowledge of herring early life history dynamics and recruitment processes, and in particular, how oceanographic processes might exert an important influence, remains at only a rudimentary level.

The study reported here was directed at understanding processes that might affect winter survival of herring larvae in the Gulf of Maine and determine recruitment to the juvenile stage. Shortly after hatching in the various coastal spawning areas, herring larvae congregate in inshore estuaries and embayments along the Maine coast throughout the fall (September to November). The densities of larvae inshore following this fall peak in abundance drop off to very low levels in mid-winter (late December and January), before a second group of fall-spawned larvae appears inshore in the spring (February through April), thus giving a bimodal abundance distribution with time (Fig. 1). To infer the overwintering distributions of those larvae that survived to the spring and aggregated inshore, we applied a new, and still experimental, technique of otolith analysis: the use of concentration ratios of strontium to calcium in the larval otoliths. Preliminary studies on herring (Radtke et al. 1989) and other species (Radtke 1984, Radtke \& Targett 1984) have suggested that these ratios are well correlated with the temperature at which the otolith aragonite was precipitated and thus the otolith acts as a biological recorder of water temperatures experienced by individual fish. We hypothesized that by applying this technique to herring larvae in the Gulf of Maine we would be able to infer the movements and distributions of individuals throughout their life history, and thus shed some light on factors affecting the survival of larvae through their first winter. 


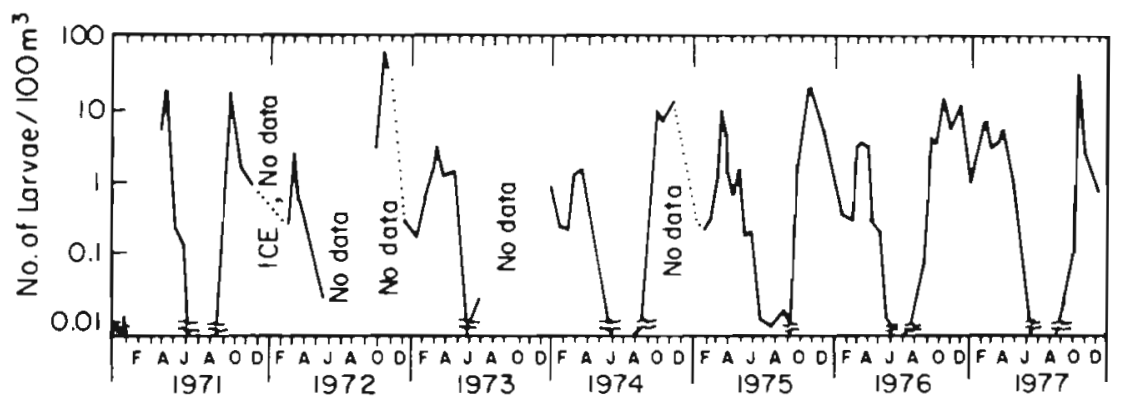

Fig. 1. Clupea harengus. Densities of larval herring sampled in the Sheepscot River estuary from 1971 to 1977 using buoyed and anchored tidal nets (redrawn from Shaw 1981). Note log scale. Sampling efforts for herring larvae in the Sheepscot estuary after 1977 did not extend beyond the first half of February and do not provide any information on the second abundance peak in late winterearly spring
This communication serves a dual purpose. First, we demonstrate the utility of the $\mathrm{Sr} / \mathrm{Ca}$ ratio technique to reconstruct environmental histories of herring larvae in the Gulf of Maine. Second, based on our preliminary results with the $\mathrm{Sr} / \mathrm{Ca}$ ratio technique we report an important finding: that nearly all of the fall-spawned herring larvae that survive to the following spring spend the mid-winter period in offshore waters in the Gulf of Maine rather than in the inshore nursery areas.

\section{Background: strontium/calcium ratios in fish otoliths}

As Radtke (1984) has shown, fish otoliths, due to their chemical makeup and incremental growth structures, can act as storage units for a wide range of environmental information, revealing past growth rates as well as important life-history and environmental transitions. Most otoliths are composed of the aragonitic form of calcium carbonate precipitated into a protein matrix (Carlstrom 1963, Degens et al. 1969), and can be contaminated by a number of trace elements. Chief among these contaminants is strontium, which has the same +2 valence as calcium, and by substituting for it, can coprecipitate into the aragonite crystal. It has been established that the degree of incorporation of strontium into the inorganically precipitated aragonitic form of calcium carbonate is inversely related to temperature (Kinsman 1969, Kinsman \& Holland 1969), but the same process is less clearly understood for biologically precipitated skeletal aragonite. Coral aragonite, for example, has been shown to have a ratio of $\mathrm{Sr}$ to $\mathrm{Ca}$ similar to that of the seawater from which it is precipitated, but there is evidence of a temperature control which results in discrimination against the incorporation of strontium at increasing temperatures (Smith et al. 1979). This temperature effect in coral is slightly greater than that for inorganically precipitated aragonite, which suggests the existence of a biological fractionation on top of the physical-chemical control. In studies of molluscs, Lowenstam (1963) has suggested that more highly evolved organisms, with more complex physiological processes, display a greater degree of discrimination against the incorporation of Sr into aragonitic materials and have ratios of Sr to Ca correspondingly lower than those of either the surrounding seawater or inorganic aragonite. This biological fractionation of strontium in higher organisms is therefore more dependent on temperature than that in the inorganic system or even corals (Hallam \& Price 1968). The trend appears to be further exaggerated in fishes, which, in preliminary tests, exhibit a much stronger temperature effect against the incorporation of Sr into otolith aragonite (Radtke 1984, Radtke \& Targett 1984, Radtke et al. 1989).

Preliminary analyses of otoliths from reared cod Gadus morhua suggested that $\mathrm{Sr} / \mathrm{Ca}$ ratios, as expected by Lowenstam (1963), are deposited relative to temperature (Radtke 1984) but with a much greater degree of discrimination against strontium, as well as a greater temperature effect, than is the case for either inorganic or coral aragonite (Fig. 2). Radtke \& Targett

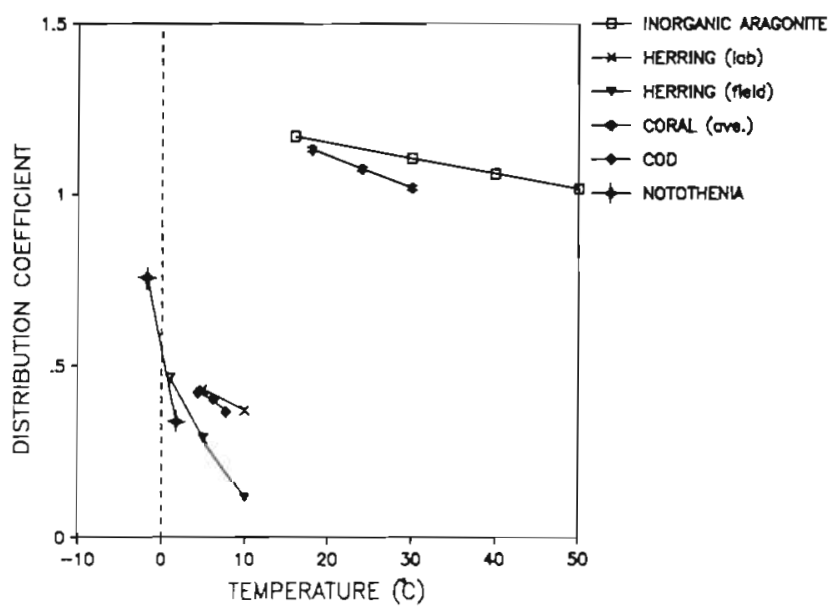

Fig. 2. Plots of distribution coefficients of $\mathrm{Sr} / \mathrm{Ca}$ (the ratio of the $\mathrm{Sr} / \mathrm{Ca}$ in aragonite to the $\mathrm{Sr} / \mathrm{Ca}$ ratio in the seawater from which it was precipitated) versus temperature for inorganic aragonite (Kinsman 1969), coral aragonite (Smith et al. 1979), cod Gadus morhua (Radtke 1984), the Antarctic fish Notothenia larseni (Radtke \& Targett 1984), and herring Clupea harengus, both reared and from field-caught fish (this study). The seawater $\mathrm{Sr} / \mathrm{Ca}$ ratios used to compute the distribution coefficients for the cod and herring otoliths are based on average seawater $\left(8.5 \times 10^{3} \mu \mathrm{g} \mathrm{I}^{-1} \mathrm{Sr}\right.$ to $4.2 \times 10^{5} \mathrm{\mu g} \mathrm{l}^{-1} \mathrm{Ca}$; Riley \& Chester 1971) 
(1984) used this principle of varying $\mathrm{Sr} / \mathrm{Ca}$ ratios with temperature to validate annual growth rings in the otoliths from an Antarctic nototheniid by matching the rings with the annual temperature cycle (ca -1.8 to $+1.8^{\circ} \mathrm{C}$ ). More significantly, Radtke et al. (1989) have shown that the $\mathrm{Sr} / \mathrm{Ca}$ ratios of reared herring larvae from the Clyde Sea were well correlated with the ambient water temperature in the rearing tanks. They concluded that, coupled with a knowledge of the growth of the fish otoliths in order to provide a time course of otolith precipitation, and with the proper calibration of $\mathrm{Sr} / \mathrm{Ca}$ ratios with temperature, the $\mathrm{Sr} / \mathrm{Ca}$ thermometry technique could become a powerful tool capable of reconstructing the environmental histories of individual fish.

\section{MATERIALS AND METHODS}

We applied the $\mathrm{Sr} / \mathrm{Ca}$ ratio otolith technique to reconstruct the temperature histories of larval herring Clupea harengus sampled during fall, winter and spring in the Sheepscot River estuary (Maine coast, USA) in 1985-86 and 1986-87. Larvae were sampled in the estuary in 1985-86 with buoyed and anchored nets (Graham \& Venno 1968), and with a meter-net the following year. Upon collection larvae were sorted and frozen at $-18^{\circ} \mathrm{C}$ for future analyses. Surface water temperatures were recorded at the time of collection, and vertical sections of the estuary were made during the winter sampling periods using a Neil Brown Smart CTD.

Laboratory analyses included recording total lengths (to the end of the caudal fin) on freshly thawed larvae, and weights after drying each larva overnight to a constant weight in an oven at $60^{\circ} \mathrm{C}$. After weighing, the larvae were stored in a vacuum desiccator until the otoliths were removed. Measurement of the diameters of sagittal otoliths were made to the nearest micrometer.

Calibration experiments to relate the $\mathrm{Sr} / \mathrm{Ca}$ ratios to the temperature at which the otolith aragonite was precipitated were performed on herring larvae reared artificially from eggs and milt from Gulf of St. Lawrence spring-spawning herring obtained in May 1987. After fertilization the eggs were allowed to incubate in temperature-controlled, flow-through tanks supplied with seawater from Boothbay Harbor. Three tanks of 751 each were maintained at 2,5 and $10^{\circ} \mathrm{C}$ by controlling the amount of refrigerated seawater flowing through them. Upon hatching, larvae were fed daily a mixture of rotifers, Artemia, and wild plankton caught in the harbor with an $80 \mu \mathrm{m}$ mesh net. Larvae were sacrificed at approximately weekly intervals, measured, dried and stored in a vacuum desiccator until the otoliths were extracted. Only those larvae which had food in their gut, and hence were assumed to be healthy, were used in subsequent analyses.

Otoliths extracted from both field-caught and reared larvae were prepared for measurements of concentration ratios of $\mathrm{Sr}$ and $\mathrm{Ca}$ in a wave-length dispersive CAMBAX X-ray electron microprobe (Radtke et al. 1989) by first grinding and polishing the specimen to the mid-plane. This was done by attaching on otolith to a 1 inch $(2.5 \mathrm{~cm})$ diameter glass disk using epoxy resin, and then grinding the otolith using $3.0 \mu \mathrm{m}$ diamond paste. Once the core region was revealed the specimen was then highly polished with $0.3 \mu \mathrm{m}$ alumina paste. The surface of the specimen to be examined with the microprobe must be extremely smooth to avoid large diffractions of X-rays, which result in analytical errors (Radtke unpubl.). Prior to analysis with the X-ray electron microprobe the specimen discs and standards were coated with a thin layer of carbon under vacuum to further dampen the diffraction of X-rays and increase electron conductance. Apatite and strontium fluoride were used as standards.

The electron microprobe focuses an electron beam on an area on the polished surface of the otolith ca $5 \mu \mathrm{m}$ in diameter where a 'spot sample' is analyzed. These sample sites on the surface of the otolith are revealed as burn depressions left by the electron beam (Fig. 3). The prepared otolith, while being analyzed in the electron microprobe, can be visually monitored using the light microscope capabilities of the instrument. We viewed the specimen under $400 \times$ magnification to locate the approximate geometric center of the otolith (the preparation is a flat, polished surface and does not display the growth increments), and then analyzed spot samples for strontium and calcium from the geometric center, or core, to the outer edge, spacing samples at 5 to $10 \mu \mathrm{m}$ intervals. Every attempt was made to insure consistent radial directions across the otoliths among specimens. The technique is described in more detail in Radtke et al. (1989).

Following the microprobe analysis for $\mathrm{Sr} / \mathrm{Ca}$ ratios, some of the otoliths were repolished with $0.3 \mu \mathrm{m}$ alumina paste (to remove the carbon coating), etched with either $7 \%$ EDTA or $0.1 \mathrm{~N} \mathrm{HCl}$, coated in a sputter coater, and examined with a scanning electron microscope. Our intent was to relate the sample marks, or burn depressions left on the surface of the otoliths by the electron microprobe, to the corresponding number of daily growth increments in the otolith. Fig. 3 shows one such otolith that was microprobed and then repolished and photographed in the SEM. The sample marks from the microprobe are visible as a series of burn depressions in the surface of the otolith. One need only count the number of daily increments between point samplings for Sr/Ca to assign dates and hence 


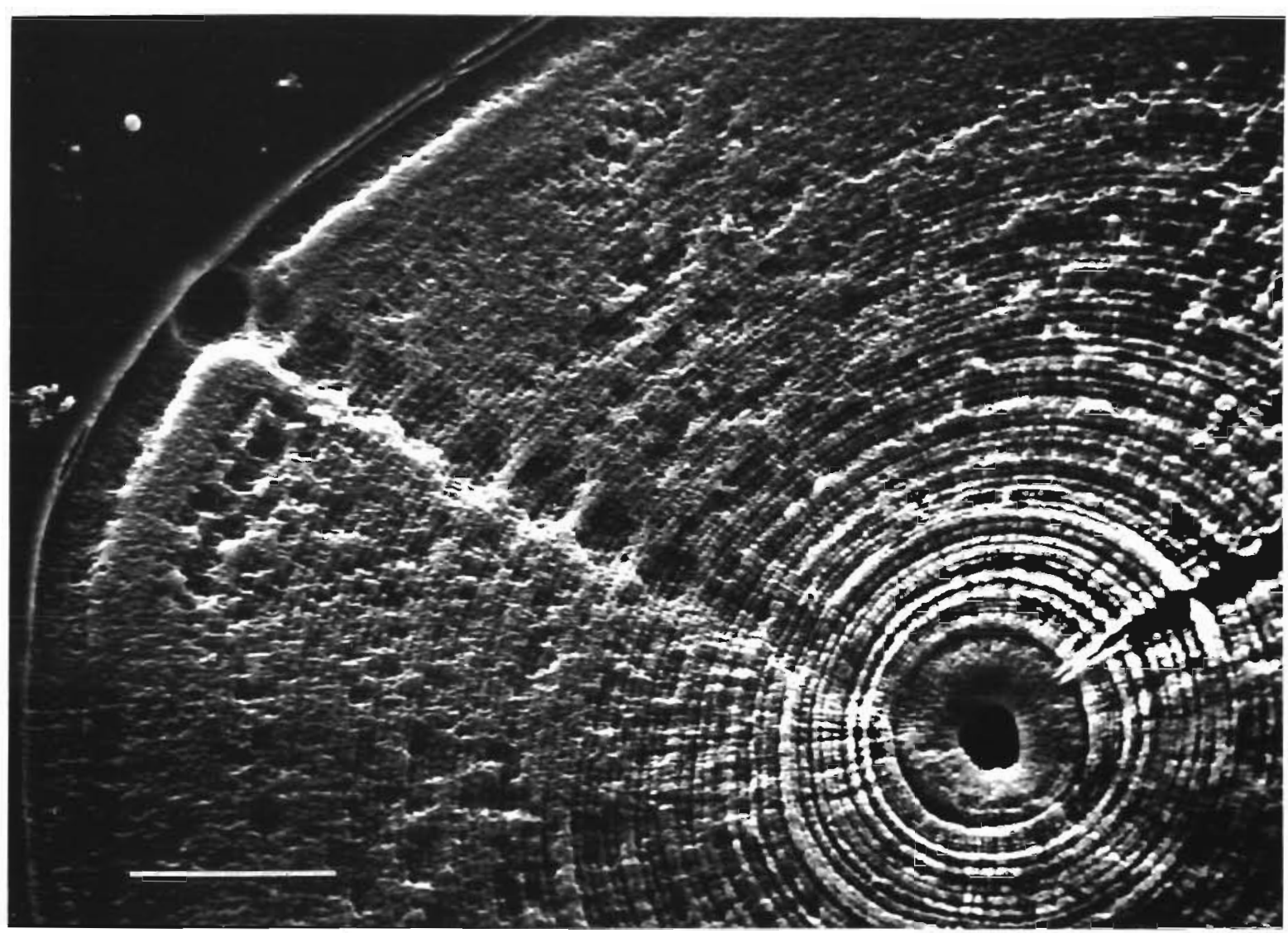

Fig. 3. Clupea harengus. Scanning electron micrograph of a larval herring otolith that had previously been sampled for Sr/Ca ratios with an electron microprobe prior to being repolished, etched in EDTA and coated for SEM examination. The spots where the microprobe sampled are visible as a series of discrete burn depressions, made by the electron beam, running from near the center of the otolith to the outer edge. Note the narrow increment widths toward the outer edge of the otolith. Scale bar $=20 \mu \mathrm{m}$

construct time courses, or histories, of water temperatures experienced by that larva.

Re-examination of a microprobed specimen with an SEM to count daily otolith growth increments was made difficult by our inability to consistently etch the increments. This can be seen in Fig. 3 which shows well-defined growth increments near the central portion of the otolith that have been well etched by the EDTA. However narrow (some less than 1 um) increments near the outer edge are fainter, having been poorly etched. Our preliminary results with dilute $\mathrm{HCl}$ suggest that it etches these narrow (presumably carbonate-poor) increments better than EDTA, which in turn etches better the wider, carbonate-rich increments.

Because of doubts still outstanding regarding the periodicity of otolith microincrement deposition rates (Campana \& Neilson 1985, Campana et al. 1988), in addition to the problems we encountered with etching the increments, we have not tried to assign the point measurements of $\mathrm{Sr} / \mathrm{Ca}$ to a particular larval age based on daily increment counts. Instead, we have assigned calendar dates for each of the Sr/Ca point samples in an otolith by using the relationship between the position of those Sr/Ca measurements, as converted to an otolith diameter at the time of precipation of that portion of the otolith, and larval length. Then, given an empirical relation between otolith growth and larval length (Fig. 4) as well as a known larval growth rate in terms of length (Fig. 5) we converted the Sr/Ca point sample to a calendar date. The details follow

Fig. 4 shows the relation between otolith diameter $(\mu \mathrm{m})$ and larval length (total length, TL, in $\mathrm{mm}$ ) for a total of 190 field-caught larvae, and a fitted logistic curve (Campana et al. 1988). The fitted equation was:

Otolith diameter $=$

$$
23.22+\frac{793.6}{1+\exp (-0.121(\mathrm{TL}-40.65))}
$$

This equation was rearranged to solve for larval length in terms of otolith diameter. Since each $\mathrm{Sr} / \mathrm{Ca}$ ratio determination was made in terms of distance in um from the center of the otolith, we doubled that value 


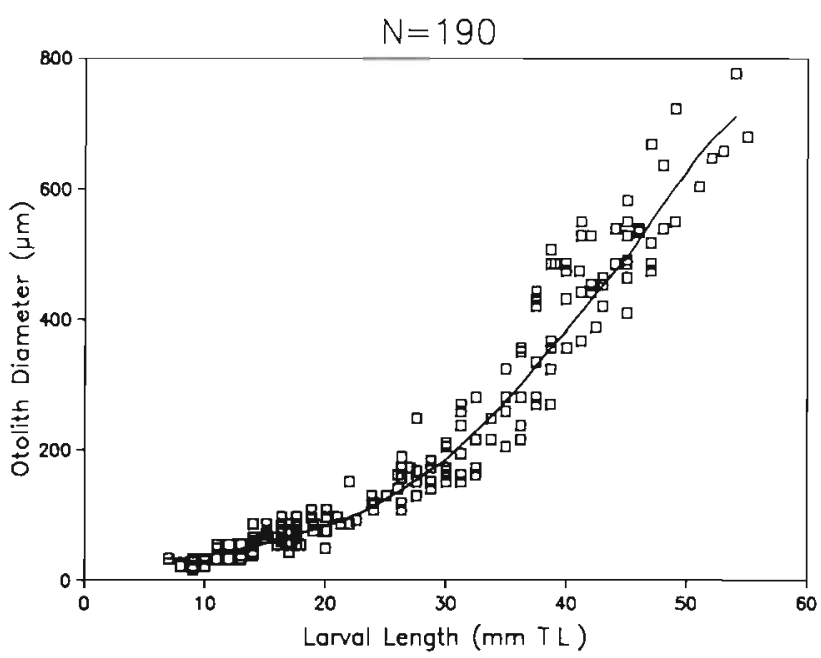

Fig. 4. Clupea harengus. Relation between diameter of sagittal otolith of herring larvae and larval length in $\mathrm{mm}$ total length. Data are for 190 field-caught larvae sampled in the Sheepscot estuary during 1986-87. The equation of the line is

Larval length $=\frac{\ln (b / \text { oto. dia }-a)-1)+d}{-c}$

The parameter estimates and their asymptotic standard errors were: $a=23.22$ (SE 11.2); $b=793.6$ (SE 65.5); $c=0.121$ (SE $0.011) ; d=40.65($ SE 1.22$)$

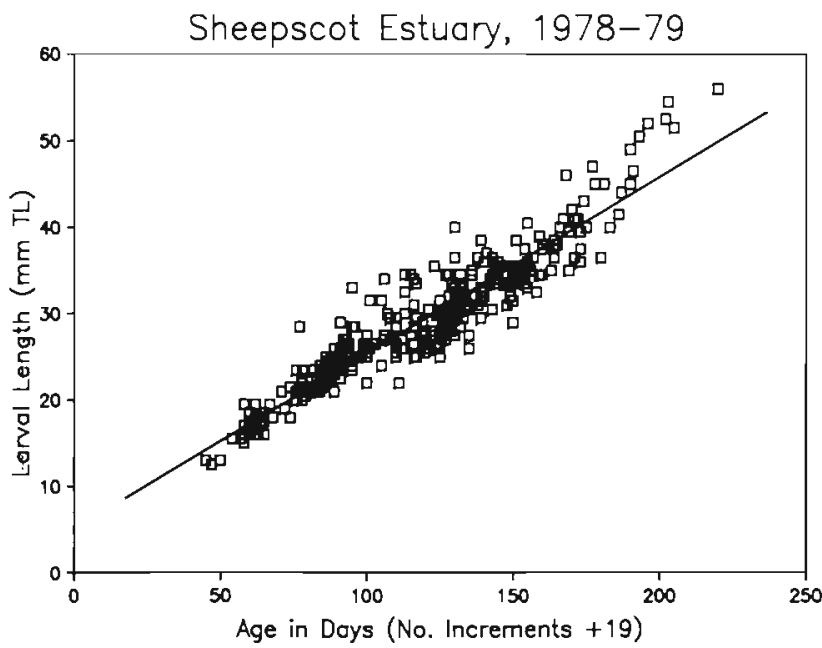

Fig. 5. Clupea harengus. Larval herring length versus age in days, assuming that it takes $22 \mathrm{~d}$ for the first 3 daily growth increments to form (Lough et al. 1982), with a fitted regression line. Data are from Townsend \& Graham (1981) for 300 herring larvae sampled in the Sheepscot estuary. The equation is: length in $\mathrm{mm}(\mathrm{TL})=5.152+0.204$ (age in days); the standard error of the intercept is 0.54 , and the standard error of the slope is 0.004

to arrive at an estimate of the otolith diameter at the time those particular quantities of strontium and calcium were deposited. That otolith diameter was then used to back-calculate the larva's length for that particular period in its life.

The larva's calculated length at the time of the measured strontium and calcium deposition was used to estimate its age in days by using a simple linear agelength relation derived from the data of Townsend \& Graham (1981). Those data included larval length and numbers of daily growth increments for larvae from the same station in the Sheepscot estuary. We regressed length against the sum of the number of increments plus 19 (Fig. 5). The addition of 19 reflects the finding of Lough et al. (1982) that the first 3 increments are formed on average during the first $22 \mathrm{~d}$ following hatching. The fitted equation was:

$$
\text { Length (mm TL) }=5.152+0.204 \text { (Age in days) }
$$

Thus each measure of $\mathrm{Sr} / \mathrm{Ca}$ from the center of the otolith to the outer edge was assigned a larval age (expressed as days after hatching) corresponding to the time of that deposition. These ages were then subtracted from the date of capture to arrive at a calendar date and plotted with the estimated temperature (from the experimentally-determined $\mathrm{Sr} / \mathrm{Ca}$ vs temperature relationship) to reconstruct that larva's temperature history.

This method of assigning dates to the estimated environmental temperatures experienced by a larva suffers from a compilation of errors associated with each of the above relations, and the method would be greatly improved by using the daily growth increments. This is a goal of our future research, but we warn that in this communication only conclusions based on general trends should be drawn from our reconstructed temperature histories.

\section{RESULTS}

\section{Rearing experiments}

The ratios of $\mathrm{Sr}$ to $\mathrm{Ca}$ as a function of temperature for the laboratory-reared larvae are presented in Fig.6a. Because of the low number of larvae that survived at $2{ }^{\circ} \mathrm{C}$, as well as difficulties we had preparing very small ( 20 to $30 \mu \mathrm{m}$ diameter) otoliths for microprobe analyses, only larvae from the 5 to $10^{\circ} \mathrm{C}$ tanks are included. However, we have added in this plot $\mathrm{Sr} / \mathrm{Ca}$ ratio samples taken from the outer edge of the otoliths from larvae collected from the Sheepscot Estuary in winter, when our CTD profiles showed the waters to be vertically isothermal at 1 and $2^{\circ} \mathrm{C}$. The $\mathrm{Sr} / \mathrm{Ca}$ at the very outer edge of those otoliths was assumed to reflect the temperature at the time of collection. The points in Fig. 6a fall on a straight line with a slope of about -7 . However, using this $\mathrm{Sr} / \mathrm{Ca}$ versus temperature relationship to assign temperatures for $\mathrm{Sr} / \mathrm{Ca}$ values in field- 

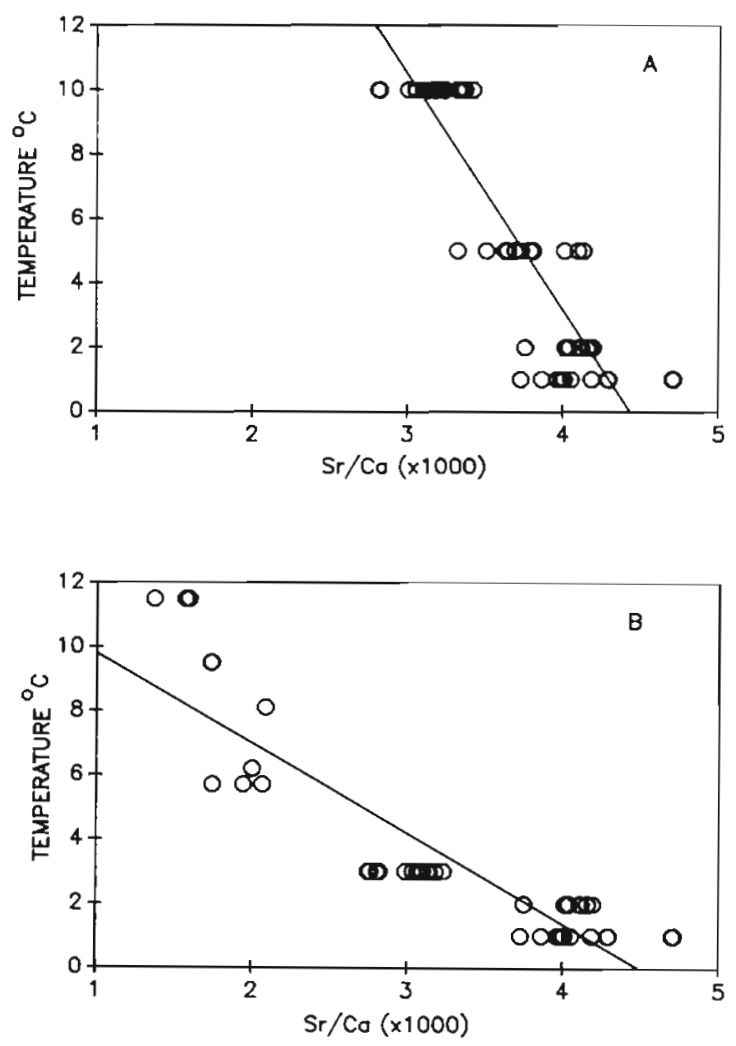

Fig. 6. Clupea harengus. Relations between Sr/Ca concentration ratios in larval herring otoliths and temperature. (A) Relation between $\mathrm{Sr} / \mathrm{Ca}$ ratios and temperature for laboratoryreared larvae at 5 and $10^{\circ} \mathrm{C}$, as well as $\mathrm{Sr} / \mathrm{Ca}$ samples from the outer edge of otoliths of field-caught larvae when the water temperature recorded in the Sheepscot estuary was 1 to $2^{\circ} \mathrm{C}$. Regression equation is Temperature $\left({ }^{\circ} \mathrm{C}\right)=32.38-7.30(\mathrm{Sr} /$ $\mathrm{Ca} \times 1000) . N=61 ; R^{2}=0.81$; standard error of intercept $=$ 1.66; standard error of slope $=0.45$. (B) Relation for outer rim analyses of field-caught larvae only. Regression equation is Temperature $\left({ }^{\circ} \mathrm{C}\right)=12.60-2.81(\mathrm{Sr} / \mathrm{Ca} \times 1000) . \quad N=46$; $R^{2}=0.79$; standard error of intercept $=0.74$; standard error of slope $=0.22$

caught larvae gave exaggerated estimates of the maximum temperatures experienced by the larvae - some estimates were as high as $25^{\circ} \mathrm{C}$. A similar plot, but using only the Sr/Ca value of the extreme outer edge of the otolith from field-caught larvae versus temperature at the time of collection, is shown in Fig. 6b. Those data show a $\mathrm{Sr} / \mathrm{Ca}$ versus temperature slope less steep (ca -3) than that for the reared larvae. This slope derived from field-caught larvae is similar to that which we saw for reared Clyde Sea herring larvae (slope $=-2.95$ ) held at the natural temperature of their flow-through system (which increased from 6 to $12^{\circ} \mathrm{C}$ during the period from March to June; Radtke et al. 1989).

The differences between the slopes of the lines in Fig. $6 \mathrm{a}$ and $\mathrm{b}$ result from there being more strontium present in the otoliths of the reared larvae than in the field-caught larvae. Such results suggested to us that the reared larvae may have been experiencing artificially induced stress which inhibited their ability to discriminate physiologically against the incorporation of strontium. Strong evidence of stress and abnormal otolith growth was revealed in the examination of the otoliths in the SEM. The otoliths from reared larvae had poorly defined daily increments, as compared to fieldcaught larvae of the same size, and had less than half the expected number of increments. Also, the growth rates of the reared larvae were less than $0.2 \mathrm{~mm} \mathrm{~d}^{-1}$, which is lower than that reported in nature (Townsend \& Graham 1981). Assuming the reared larvae were stressed would explain the greater dependence of $\mathrm{Sr} /$ $\mathrm{Ca}$ on temperature than was seen for the field-caught larvae. This result of stress would in fact be expected based upon Lowenstam's (1963) suggestion of a physiologically controlled temperature regulation, which discriminates against strontium incorporation at higher temperatures. Conversely, it could be argued that there are other, as yet unknown, factors which affect the incorporation of strontium in larval herring otoliths. We would emphasize, therefore, that any future laboratory work directed toward calibrating the $\mathrm{Sr} / \mathrm{Ca}$ ratio technique should be carried out with extreme caution. The inferred temperatures we present in this communication are based upon the $\mathrm{Sr} / \mathrm{Ca}$ versus temperature relationship determined from the outer-rim analyses of otoliths from field-caught larvae only, and the calculated calendar dates to which these estimated temperatures are assigned are determined from empirical relationships among otolith size, larval lengths and larval ages as discussed above.

\section{Estuary catch rates and temperatures}

The catch rates of herring larvae in the Sheepscot River estuary and surface water temperatures at the time of collection are presented in Fig. 7. In both years of our study these estimates of relative abundances of larvae reached a peak in the fall and then again in the spring, as had been reported by Shaw (1981) in years past (Fig. 1). Based on the catch rates determined by the buoyed and anchored nets employed in 1985-86, the relative abundances reached about 7.3 larvae $100 \mathrm{~m}^{-3}$ on November 6,1985 , before dropping to a low of 0.6 larvae $100 \mathrm{~m}^{-3}$ on December 16. This period of low mid-winter abundance in the estuary was followed by a second peak of about 3.7 larvae $100 \mathrm{~m}^{-3}$ on the last sample day, February 26, 1986. Thus the relative abundances of herring larvae in the Sheepscot estuary were reduced by about $50 \%$ between November 6 and February 26 - an exceptionally low mortality rate, should those larvae present in the spring be the same group 

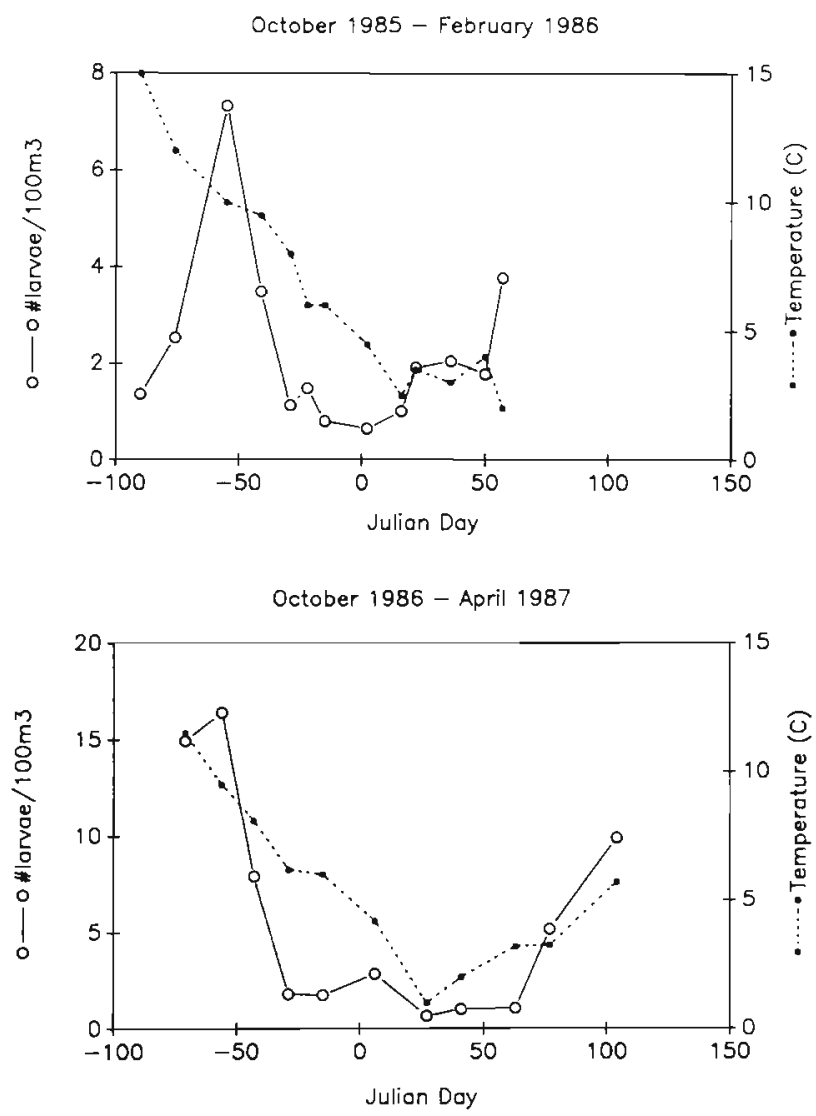

Fig. 7. Clupea harengus. Surface temperatures and catch rates of herring larvae in the Sheepscot estuary 1985-86 and 1986-87. Dates are given as Julian day, with $1=$ January 1. Data from 1985-86 are from buoyed and anchored tidal nets; the following year's samples were collected with a meter net

which entered in the fall. This observation alone would suggest that larvae present in the spring have arrived from somewhere else, having spent the mid-winter period of low larval abundance outside the estuary. The trend was similar for the $1986-87$ season. The fall peak occurred on November 5, with about 16.4 larvae $100 \mathrm{~m}^{-3}$, dropped to a low of 0.66 on January 27 , and increased again in the spring to 9.9 larvae $100^{-3}$; again, the larval abundance in the spring was about $50 \%$ that in the fall shortly after spawning.

The period of low mid-winter abundance in the estuary in 1985-86 occurred as water temperatures in the estuary were dropping below $5^{\circ} \mathrm{C}$, and the spring peak began when the water temperature was between 2 and $4^{\circ} \mathrm{C}$. The decrease in abundance in the second year showed a similar trend in that the abundances were reduced to very low levels well before the water temperatures were at their minimum. But unlike the previous year the springtime peak began when the temperatures were past the minimum.

\section{Temperature histories of larvae}

The temperature histories of larvae collected in the Sheepscot Estuary on February 26, 1986, are shown in Fig. 8. The inferred temperatures experienced by each individual larva throughout its life history are all plotted together to facilitate the recognition of the general

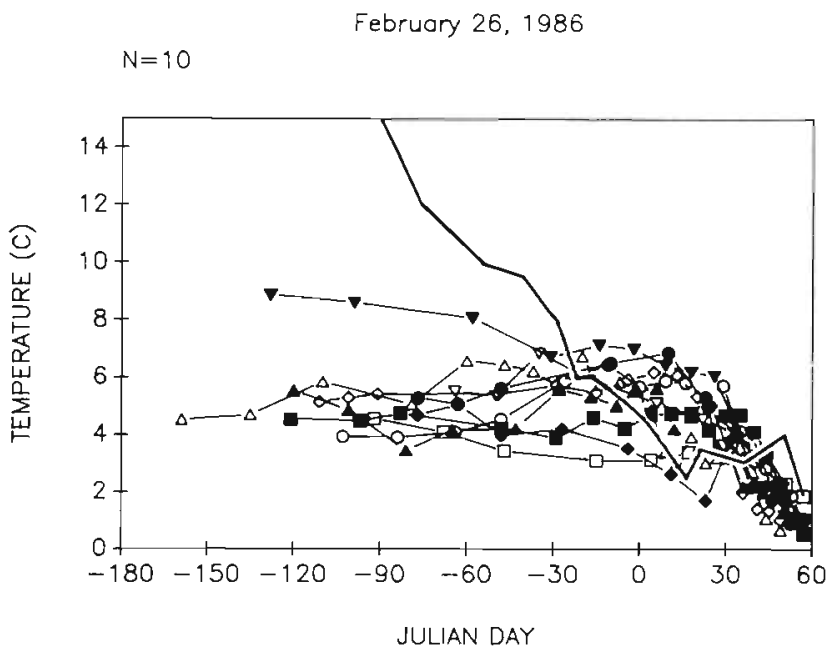

Fig. 8. Clupea harengus. Reconstructed temperature histories for 10 herring larvae sampled in the Sheepscot estuary on February 26, 1986. Estimated temperatures experienced by each larva over the fall and winter period prior to capture are based on the $\mathrm{Sr} / \mathrm{Ca}$ ratio measurements across an individual otolith. Dates (expressed as Julian dayl are back-calculated from the date of capture (February 26, or Julian Day 57) based on the otolith diameter corresponding to each $\mathrm{Sr} / \mathrm{Ca}$ sample (see text). Solid line: actual water temperatures recorded in the Sheepscot estuary during fall and winter

trend in temperature histories for that group of larvae; the water temperatures in the Sheepscot estuary are plotted as a solid line for comparison. Though this produces a busy plot, it is the best way to see the pattern of the group as a whole.

That the calculated water temperatures experienced by these 10 larvae during the fall, or early in their life history, are colder than those in the estuary during the fall (Fig. 8), is to be expected. The larvae are spawned in tidally-mixed coastal waters which remain colder in the late summer and fall than the shallower inshore waters which are warmed more effectively. Should these larvae captured in late February, during the spring peak in larval abundance inshore, be the same group which entered the estuary in the fall, we would expect to see the calculated temperature histories follow closely the temperatures in the estuary from the fall to the time of capture. The time they would have entered the estuary in the fall would correspond approximately to Julian Day -50 in our plots in Fig. 8 
(early November), matching the time of maximum larval abundance (Fig. F), and corresponding to temperatures in the estuary greater than $14^{\circ} \mathrm{C}$. This did not appear to be the case, since we calculated the temperatures experienced by the larvae to be well below $14^{\circ} \mathrm{C}$, suggesting to us that these larvae resided in the cooler waters outside the estuary through the fall. In addition, the reconstructed temperature histories showed that the larvae sampled in February had occupied waters during the mid-winter period (January, or Julian Days 0 to 30 in Fig. 8) that were warmer than in the estuary. After Day 30 the temperatures experienced by the larvae began to drop, approaching those of the estuary and reflecting the entry of the larvae from the relatively warm winter waters offshore into the colder estuarine waters.

Data for the following year include temperature histories for larvae that were sampled throughout the season, from October 1986, to April 1987. Fig. 9a shows the reconstructed temperature histories of larvae sampled in the Sheepscot estuary in October and November during the fall peak (Fig. 7). The rising temperature trend which we infer the larvae to have experienced during that fall supports the contention of the larvae having been transported from the cooler, tidally-mixed coastal spawning grounds to the warmer estuary.

The temperature histories of larvae sampled on January 27 (Fig. 9b) suggest that that group of larvae was in the estuary and experienced the falling temperatures there. Judging from the time when their temperatures begin to follow those of the estuary, we estimate that this group of larvae entered the estuary ca $20 \mathrm{~d}$ before their capture.

Those larvae sampled in March and April (Fig. 9c, d), however, show evidence of not having been in the estuary either in the fall, as part of the fall larval abundance peak inshore, or during the mid-winter
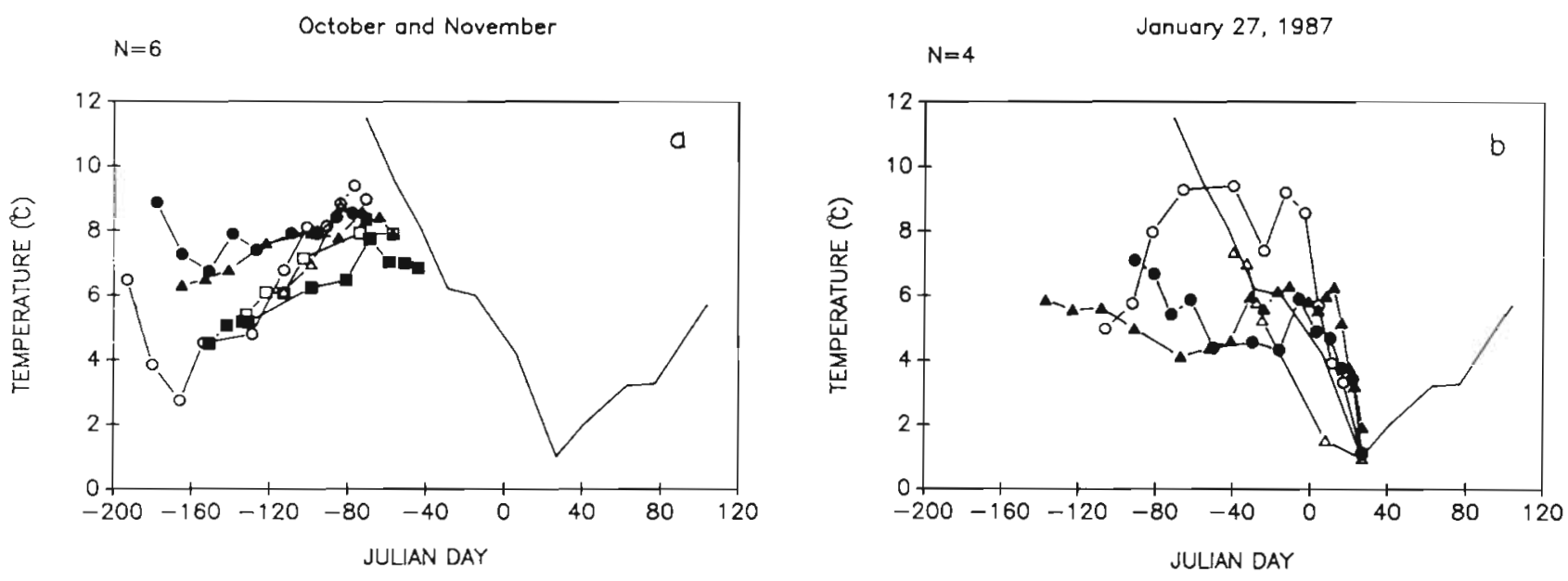

$N=14 \quad$ March 18,1987
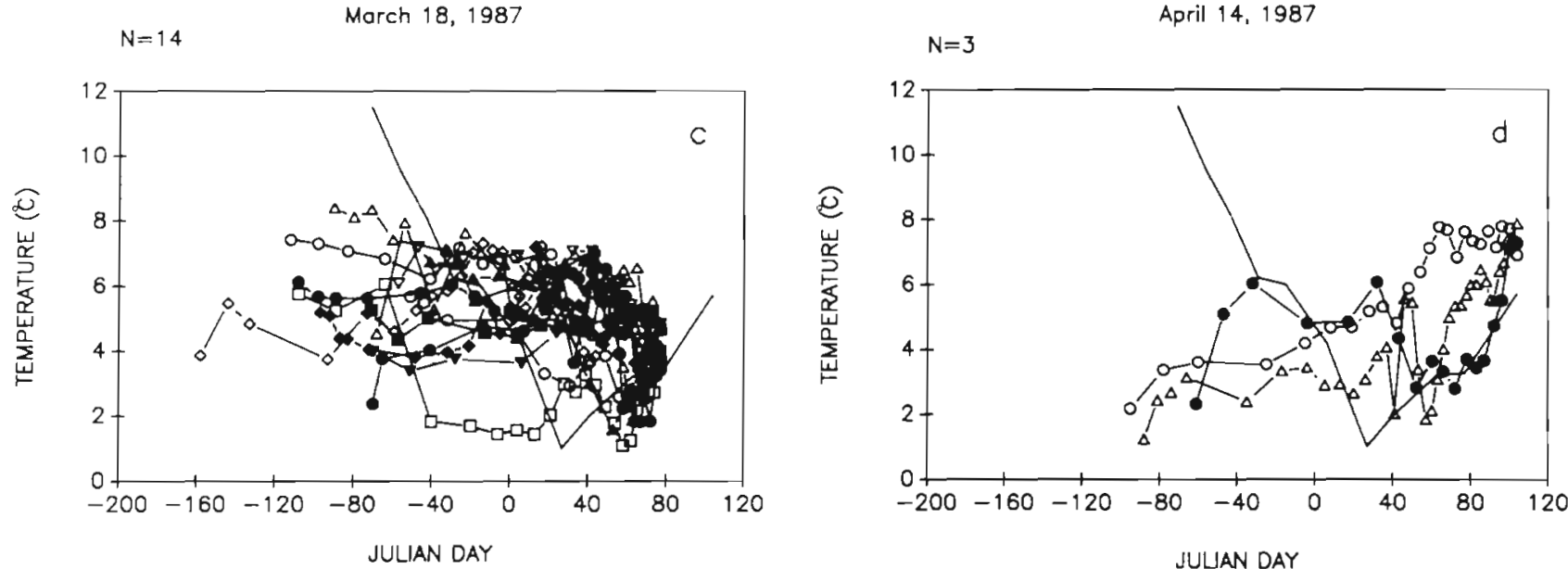

Fig. 9. Reconstructed temperature histories of herring larvae sampled in the Sheepscot estuary throughout the 1986-87 season plotted along with the water temperature in the estuary (same as in Fig. 9). Samples collected in October and November are plotted together in (a). Number of individuals in each panel is given 
period of low larval abundance inshore. The group of larvae caught on March 18 (Fig.9c) shows a general trend of having started out in waters colder than recorded in the estuary in the fall, followed by having been in waters warmer than in the estuary in January and February (Days 0 to 60). The temperature histories corresponding to the fall abundance peak (Julian Days -80 to -40 , or October to November) suggest that those larvae were in cooler waters as compared with the temperature histories of the larvae shown in Fig. 9a. This suggests to us that the larvae captured in March and April were not transported into the warmer estuary during the fall, as were the groups shown in Fig. 9a, b, but rather some time later when water temperatures in the estuary were much colder. The larvae sampled on. March 18 (Fig. 9c) appear to have been in waters warmer than the estuary during the mid-winter period; the inferred temperatures that they experienced do not match up with the temperatures in the estuary until approximately Julian Day 65, or early March. That corresponds closely with the beginning of the spring increase in larval catch rates in the estuary (Fig. 7).

We would conclude from these data that the larvae that entered the estuary in the fall are not the same larvae sampled in the estuary the following spring, and that those larvae that survive the winter have resided outside the estuary from the time they hatch until entering in the late winter and spring. An obvious exception is the individual plotted as open squares in Fig. 9c, which appears to have experienced cold waters in late November and December (Julian Days -40 to $0)$. Other than an error in the analysis, we can think of no plausible explanation for this individual's pattern.

\section{DISCUSSION}

\section{Relation to Gulf of Maine hydrography}

Assigning confidence to any inferred distributions of larvae prior to their entrance into the estuary in spring requires not only a well-defined temperature versus $\mathrm{Sr} /$ Ca relationship, but a fundamental understanding of the hydrography of the Gulf of Maine in mid-winter. More to the point, it calls for a clear picture of the distributions of water masses based solely on temperature. And although this is in fact a complicated proposition, we can draw upon some generalities regarding the water temperatures in the Gulf of Maine.

During late summer and autumn when herring spawn in the Gulf of Maine area, there are significant areal differences in bottom water temperatures where the demersal eggs develop and form the nucleus of the otolith. These bottom temperature differences between areas of similar depth arise from variations in the inten- sity of vertical mixing by tides; areas which are vertically well-mixed have warmer bottom temperatures (from the downward mixing of surface waters, warmed by solar insolation), while beneath the more stratified waters, principally in the western Gulf, bottom waters are isolated from the warmer surface and are cooler. For instance, bottom water temperatures in the vicinity of western Gulf of Maine spawning grounds are generally 4 to $5^{\circ} \mathrm{C}$ while those in the eastern Gulf are generally above $7^{\circ} \mathrm{C}$ (Colton et al. 1968. Townsend et al. 1987 a). Water temperatures in the relatively shallow inshore areas, as seen in Fig. 7 for the Sheepscot estuary, are much warmer through the early fall when the first pulse of herring larvae appears. The temperature histories of the larvae in Fig. 9a indicate such a movement from coastal to inshore waters. Unfortunately, we cannot at this time discriminate differences in early life temperature histories accurately enough to infer probable spawning sites.

During winter, bottom water temperatures are much more uniform for areas of similar depth as a result of convective overturn. In fact the water column is vertically isothermal throughout much of the Gulf of Maine, excluding the deep basins in the center of the Gulf where warm, high salinity slope water rests year-round (below $140 \mathrm{~m}$; Bigelow 1927, Hopkins \& Garfield 1979; Fig. 10). During winter there are horizontal temperature gradients in the Gulf of Maine which tend to parallel the isobaths (Colton et al. 1968); cooling is more complete in shallower waters and, although vertically isothermal, the horizontal difference from inshore estuaries and embayments to the coastal waters beyond the headlands is 3 to $4{ }^{\circ} \mathrm{C}$ (Fig. 10). For this reason we suggest that those larvae which appear to have experienced water temperatures in mid-winter that were warmer than the inshore estuary, have in fact spent that period somewhere offshore.

\section{Inferred movements of larvae}

Because the deeper waters offshore do not become cooled as quickly or as completely as the shallow inshore waters, we would suggest, based upon our temperature history data, that following hatching along the coast a significant portion of that autumn's herring larvae occupied coastal or offshore waters through the mid-winter period, but not inshore waters. Larvae that entered the estuaries in the fall do not appear to have survived the winter. Had the larvae that survived to the spring entered the estuary in the fall we would have seen a warm water signal in the $\mathrm{Sr} / \mathrm{Ca}$ ratios similar to the signal in the larvae sampled in October and November as seen in Fig. 9a. We suggest, then, that the spring survivors entered the Sheepscot estuary in late 

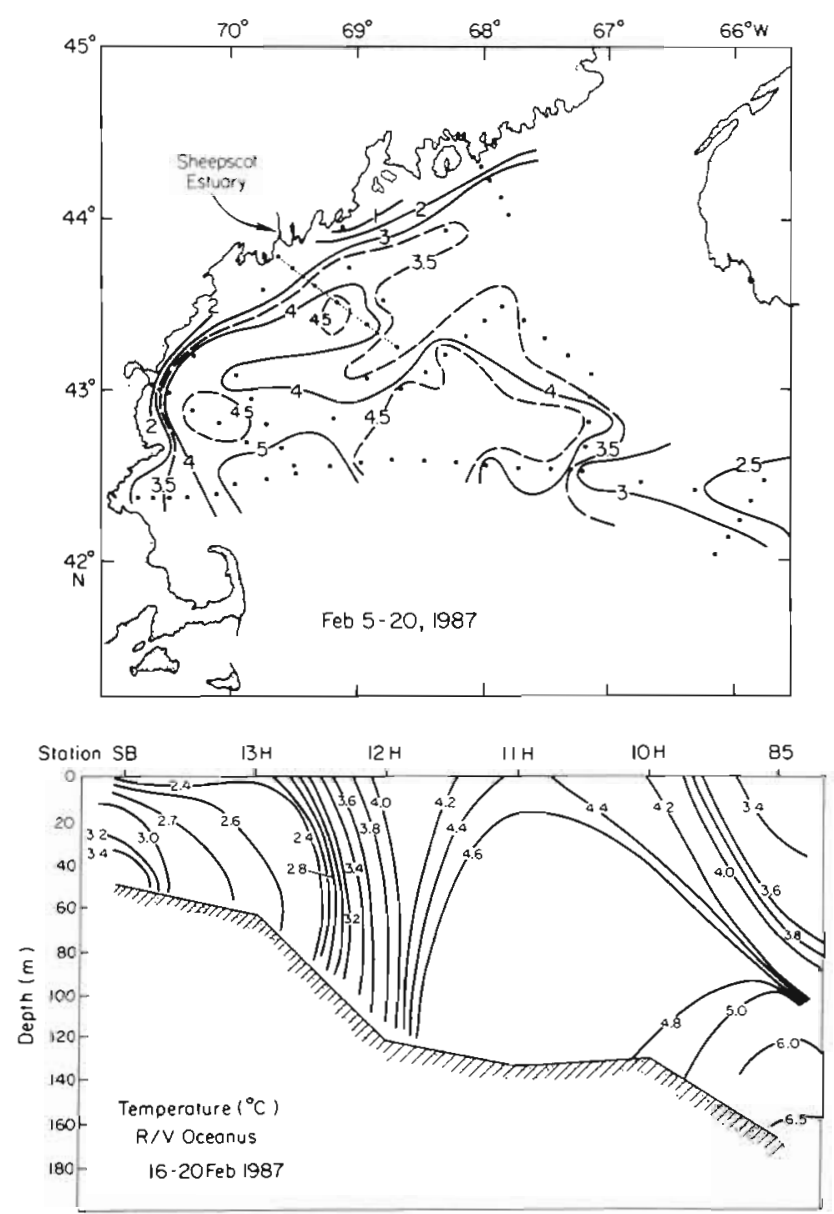

Fig. 10. Upper: distribution of surface water temperatures (at $5 \mathrm{~m}$ ) in the Gulf of Maine in winter 1987, compiled from 2 cruise legs on the RV 'Oceanus', 5 to 15 February (W. Brown unpubl.) and 16 to 20 February (Townsend et al, 1987a). Lower: vertical section plot corresponds to the transect shown by the dotted line in the upper panel

January and February in 1986 and somewhat later in 1987 .

It is unlikely that vertical migrations by herring larvae would cloud our measures of temperature histories. During mid-winter, our period of interest, vertically migrating larvae which might have resided over the central offshore basins would be encountering water at the bottom, should they go as deep as $140 \mathrm{~m}$, that is $>6^{\circ} \mathrm{C}$ (Colton et al. 1968). Should larvae be migrating into and out of this warm bottom water of slope water origin, the result would be an averaging of the deep and surface temperatures which would cause us to overestimate (by 1 or $2^{\circ} \mathrm{C}$ ) the ambient temperatures encountered by larvae residing offshore. This would not confound our discrimination between residence of larvae in cold, inshore or in warm, offshore waters. Such migrations, in fact, would enhance our ability to discriminate between the 2 possible environments.
Furthermore, these relatively restricted locations in the Gulf represent the only areas of thermal stratification in winter (actually these are temperature inversions); waters around the rest of the Gulf are more nearly isothermal from top to bottom (e.g. Fig. 10). Vertical migrations by larvae in waters outside the central basins, particularly in inshore areas, would not be detected.

A general picture for the distributions of surface water temperatures in winter for the Gulf of Maine region is given in Fig. 10a for the period 5 to 20 February, 1987 (Townsend et al. 1987a, W. Brown unpubl.). Clearly evident in that plot is a slug of cold water extending from the eastern Gulf of Maine into the central area, isolating warmer waters to the north and south of it. The coldest waters are inshore. The vertical section plot of temperature along the transect of stations in Fig. 10a is shown in Fig. 10b demonstrating that the slug of cold water extends to the bottom. This cold water feature has been described for the warmer months as being tidally-mixed waters from the eastern Maine coast which have been advected to the southwest (Townsend et al. 1987b). The process apparently persists into the winter, and in so doing results in a complex hydrographic picture which might explain some of the temperature histories in Fig. 9. That is, any larvae that might have been well offshore would have to have passed through this slug of cold water before encountering first the slightly warmer coastal water and finally the very cold inshore waters.

\section{Recruitment implications}

Graham (1982) has suggested that winter survival and spring abundance of herring larvae in northern Gulf of Maine waters are important factors that affect recruitment to the Maine juvenile herring (sardine) fishery. He has reported significant correlations among winter survival, spring abundance and recruitment, yet poor correlations between fall abundance (of young larvae) and recruitment. Graham (1982) also noted that late spawning, and hence younger overwintering larvae, may increase the number of larvae surviving to the spring. The causes of winter mortality are not known, but could include predation by any of a suite of invertebrates (e.g. Bailey 1982, 1984, Bailey \& Batty 1983, Bailey \& Yen 1983, Brewer et al. 1984, Möller 1984) as well as food Limitation. The springtime aggregation of older larvae inshore in Maine occurs about the time of the often intense inshore phytoplankton and zooplankton blooms (Townsend 1984); the larvae metamorphose to juveniles soon thereafter. The number of larvae surviving to this important life history transition (Sinclair \& Tremblay 1984) appears to be closely coupled to recruitment success. 
Our reconstructions of the temperature histories of those larvae that survive to the spring suggest that during the winter they have occupied offshore waters rather than the inshore estuarine waters. In fact, we would suggest that it would be deleterious for larvae to be transported into the estuaries and inshore areas rather than to the offshore waters. A simple examination of the densities of larvae in the Sheepscot estuary in the fall and spring, as shown in Fig. 7, shows that it is unlikely that the larvae present in the spring are the same as entered in the fall after spawning. The extremely low mortality rates required to explain these density changes in the estuary between the fall and spring are beyond reason. Should we be correct in our hypothesis, that survival to the spring and subsequent recruitment is enhanced for those larvae which spend the winter offshore, we would need a mechanism to account for the unpredictable and interannually variable nature of recruitment. That is, whatever might increase the relative proportion of larvae that spend the winter offshore might be expected to favor winter survival. Put still another way: whatever might prevent larvae from entering the estuaries in the fall would enhance survival. Brooks \& Townsend (1989) have observed that the coastal current along the coastal Gulf of Maine, which is presumed to transport larvae away from the eastern Maine spawning ground (Townsend et al. 1986), is extremely variable, being subject to redirection as a function of the amount of dense slope water residing immediately offshore in Jordan Basin. The amount of that slope water which enters the Gulf of Maine is in turn likely influenced by the presence of warm core Gulf Stream rings at the mouth of the Northeast Channel (Townsend \& Spinrad 1986, Brooks 1987), and hence is an unpredictable and variable phenomen. It is not inconceivable that episodes of greater offshore transport of larvae, at least from the eastern Gulf of Maine, result in better survival through the winter. Processes that could influence the spawning grounds in the western Gulf of Maine might be similarly influenced since waters in the eastern and western sectors of the inner Gulf of Maine appear to be tightly coupled by a mesoscale anticyclonic eddy in the center of the Gulf. This feature is commonly observed in satellite infrared images of sea surface temperature, and is in fact the downstream end of the eastern coastal plume current (Townsend et al. 1987b).

Recently, Chenoweth et al. (1989) suggested that a significant portion of those larvae spawned in the eastern Gulf of Maine may be retained in the vicinity of the spawning grounds, at least until late October when the hydrographic structure delineating the frontal boundary between the tidally-mixed and stratified areas disappears. This hypothesis of retention of larvae in the vicinity of the tidally-mixed spawning grounds was first put forth by Iles \& Sinclair (1982). Chenoweth et al. have modified that view somewhat by suggesting that larval retention in the eastern Gulf of Maine spawning ground is incomplete. They showed that some of the larvae are retained while others (approximately half) appear to be advected to the west as was suggested by Townsend et al. (1986). It is possible, then, that the larvae we see arriving in the estuaries in the spring are in fact those that had been retained in the eastern Maine tidally-mixed spawning area until later in the fall. More detailed analyses of the $\mathrm{Sr} / \mathrm{Ca}$ in the cores of the otoliths of those larvae collected over the spawning grounds must be compared with those larvae sampled inshore in the spring before we can speculate further as to whether larvae that spend the winter outside of the estuaries do so because of their being advected offshore, or because they have been retained until late fall in the vicinity of the spawning grounds.

The origins of the larvae that appear in the Sheepscot estuary in the fall are difficult to determine based on our results using the $\mathrm{Sr} / \mathrm{Ca}$ technique. However, of the admittedly few individual temperature histories plotted in Fig. 9a, it might appear that there are 2 cohorts represented: one cohort having originated in waters somewhat warmer than the other. Should this trend be real, we might expect that the estuary receives a mixture of larvae from the eastern Gulf of Maine area, which has relatively warm bottom water temperatures, together with larvae from the western Gulf, which has relatively cold bottom water temperatures.

Regardless of the origins of larvae in the fall, or how offshore larval transport is mediated, one of the more important questions raised by these results is why survival of herring larvae in offshore waters is likely to be greater than in inshore waters. The higher temperatures offshore, especially at depth, might favor a more rapid development and hence reduce the time when the larvae are most susceptible to predation. Having survived the winter, their inshore migration may be related to the intense spring bloom of potential food items in the inshore Gulf of Maine waters which occurs in February and March (Townsend \& Spinrad 1986). In fact, the appearance of the springtime peak in herring larvae is coincident with the peak in total annual abundance of all species of fish larvae in coastal Maine waters which is believed to be related to the production cycle of their zooplankton food (Townsend 1984). This then leads us back to the question of their food supply during winter in the offshore waters; we can only speculate that they depend on overwintering copepods which reside at depth in the offshore Gulf. More field work is obviously needed before we can state for certain that the larvae spend the winter offshore, and only then can we look more closely into their ecology 
Finally, we emphasize that this work should be regarded as preliminary, having relied on a technique still being developed, but we feel that with continued developed the $\mathrm{Sr} / \mathrm{Ca}$ technique holds great promise for providing answers to numerous other important questions in fisheries oceanography.

Acknowledgements. We thank the Canadian Department of Fisheries and Oceans for supplying the ripe herring used for our rearing experiments. We also thank David Libby of the Maine Department of Marine Resources for allowing us to use his larval fish rearing facilities, and Erica Woolson for assistance in the laboratory. Thanks go to Wendell Brown from the University of New Hampshire for sharing his hydrographic data from the RV 'Oceanus' cruise Leg 1, used in Fig. 10, and Joe Graham and David Stevenson of the Maine Department of Marine Resources for supplying samples of larvae, as well as catch rates and water temperatures from the Sheepscot estuary for the 1985-86 season. This work was funded by National Science Foundation grants OCE-8614187 to DWT and OCE8617522 to R.L.R. This is Bigelow Laboratory for Ocean Sciences Contribution No. 89013

\section{LITERATURE CITED}

Bailey, K. M. (1982). The early life history of the Pacific Hake, Merluccius productus. Fish. Bull U.S. 80: 589-598

Bailey, K. M. (1984). Comparison of laboratory rates of predation on five species of marine fish larvae by three planktonic invertebrates: effects of larval size on vulnerability. Mar. Biol. 79: 303-309

Bailey, K. M., Batty, R. S. (1983). A laboratory of predation by Aurelia aurita on larval herring Clupea harengus: experimental observations compared with model predictions. Mar. Biol. 72: 295-301

Bailey, K. M., Yen, J. (1983). Predation by a carnivorous marine copepod, Euchaeta elongata Easterly, on eggs and larvae of the Pacific hake, Merluccius productus. J. Plankton Res. 5: 71-82

Brewer, G. D., Kleppel G. S., Dempsey, M. (1984). Apparent predation on ichthyoplankton by zooplankton and fishes in nearshore waters of southern California. Mar. Biol. 80: 17-28

Bigelow, H. B. (1927). Physical oceanography of the Gulf of Maine. Bull. U.S. Bur. Fish. 40: 511-1027

Brooks, D. A. (1987). The influence of warm-core Gulf Stream rings on slope water entering the Gulf of Maine. J. geophys. Res. 92(C8): 8183-8196

Brooks, D. A.., Townsend, D. W. (1989). Variability of the coastal current and nutrient pathways in the Gulf of Maine. J. mar. Res. (in press)

Campana, S. E., Neilson, J D. (1985). Microstructure of fish otoliths. Can. J. Fish. Aquat. Sci. 42: 1014-1932

Campana, S. E., Gagne, J. A., Munro, J. (1988). Otolith microstructure of larval herring: image or reality? Can. J. Fish. Aquat. Sci. (in press)

Carlstrom, D. (1963). Crystallographic study of vertebrate otoliths. Biol. Bull. mar. biol. Lab., Woods Hole 125: $441-463$

Chenoweth, S. B., Libby, D. A., Stephenson, R. L., Power, M. J, (1989). Origin and dispersion of larval herring (Clupea harengus L.) in coastal waters of eastern Maine and southwestern New Brunswick. Can. J. Fish. Aquat. Scı. 46 (4): $624-632$
Colton, J. B. Jr., Marak, R. R., Nickerson, S., Stoddard, R. (1968). Physical, chemical and biological observations on the continental shelf, Nova Scotia to Long Island, 1964-1966. U.S. Fish. Wildl. Serv., Data Report 23, p. $1-190$

Degens, E. T., Deuser, W. G., Haedrich, R. L. (1969) Molecular structure and composition of fish otoliths. Mar Biol. 2: 105-113

Graham, J. J. (1982). Production of larval herring, Clupea harengus, along the Maine coast, 1964-1978. J. Northw. Atl. Fish. Sci. 3: 63-85

Graham, J. J., Venno, P. M. W. (1968). Sampling larval herring from tidewaters with buoyed and anchored nets. J. Fish. Res. Bd Can. 25: 1169-1179

Hallam, A., Price, N. B. (1968). Environmental and biochemical control of strontium in shells of Cardium edule. Geochim. Cosmochim. Acta 32: 319-328

Hopkins, T. S. Garfield, N. (1979). Gulf of Maine intermediate water. J. mar. Res. 37: 103-139

Iles, T. D. Sinclair, M. (1982). Atlantic herring: stock discreteness and abundance. Science 215: 627-633

Kinsman, D. J. J. (1969). Interpretation of $\mathrm{Sr}^{+2}$ concentrations in carbonate minerals and rocks. J. sedim. Petrol. 39: $486-508$

Kinsman, D. J. J., Holand, H. D. (1969). The co-precipitation of cations with $\mathrm{CaCO}_{3}$ - IV The co-precipitation of $\mathrm{Sr}^{+2}$ with aragonite between 16 and $96^{\circ} \mathrm{C}$. Geochim. Cosmochim. Acta 33: 1-17

Lough, R. G., Pennington, M., Bolz, G. R., Rosenberg, A. A. (1982). Age and growth of larval atlantic herring, Clupea harengus L., in the Gulf of Maine-Georges Bank region based on otolith growth increments. Fish. Bull U.S. 80: $187-199$

Lowenstam, H. A. (1963). Sr/Ca ratio of skeletal aragonites from recent marine biota at Palau and from fossil gastropods. In: Craig, H., Miller, S. L., Wasserburg, G. J. (eds.) Isotopic and cosmic chemistry. North Holland Publ. Co., Amsterdam, p. 114-132

Möller, G. (1984). Reduction of a larval herring population by jellyfish predator. Science 224: 621-622

Radtke, R. L. (1984). Cod fish otoliths: information storage structures. Flodevigen rapportser. 1: 273-298

Radtke, R. L., Targett, T E. (1984). Rhythmic structural and chemical patterns in otoliths of the Antarctic fish Notothenia larseni: their application to age determination. Polar Biol. 3: 203-210

Radtke, R. L., Townsend, D. W., Folsom, S. D., Morrison, M. A (1989). Strontium: calcium ratios in larval herring otoliths as indicators of environmental histories. Environ. Biol Fish. (in press)

Riley, J. P., Chester, R. (1971). Introduction to marine chemistry. Academic press, New York

Shaw, R. F. (1981). Seasonal species composition, diversity, spatial distributions, and tidal retention and transport of ichthyoplankton in the Sheepscot River - Back River Montsweag Bay estuarine system, Maine. Ph. D. thesis, Univ. of Maine

Sinclair, M., Tremblay, J. J. (1984). Timing of spawning of Atlantic herring (Clupea harengus) populations and the Match-Mismatch Theory. Can. J. Fish. Aquat. Sci. 41 $1055-1065$

Sindermann, C. J. (1979). Status of Northwest Atlantic herring stocks of concern to the United States. NMFS/NEFC, Sandy Hook Laboratory, Tech. Ser. Rep. No. 23, p. 1-449

Smith., S. V., Buddemeier, R. W., Redalje, R. C., Houck, J. E. (1979). Strontium-calcium thermometry in coral skeletons. Science 204: 404-407 
Townsend, D. W. (1984). Comparison of inshore zooplankton and ichthyoplankton populations of the Gulf of Maine. Mar. Ecol. Prog. Ser. 15: 79-90

Townsend, D. W., Graham, J. J. (1981). Growth and age structure of larval Atlantic herring. Clupea harengus harengus, in the Sheepscot River estuary, as determined by daily growth increments in otoliths. Fish. Bull. U. S. 79: 123-130

Townsend, D. W., Graham, J. J., Stevenson, D. K. (1986). Dynamics of larval herring (Clupea harengus L.) production in tidally mixed waters of the eastern coastal Gulf of Maine. In: Bowman, J. J., Yentsch, C. M., Peterson, W. T. (eds.) Tidal mixing and plankton dynamics. Springer-Verlag, Berlin, p. 253-277

This article was presented by Dr K. R. Sherman, Narragansett, Rhode Island, USA
Townsend, D. W. Spinrad, R. W. (1986). Early spring phytoplankton blooms in the Gulf of Maine. Cont. Shelf Res. 6: 515-529

Townsend, D. W., Cammen, L. M., Morrison, M. A. (1987a). Wintertime oceanographic conditions in the Gulf of Maine, 16-20 February, 1987: chlorophyll, nutrient and hydrographic data. Bigelow Laboratory for Ocean Sciences. Tech. Rep. No.62, p. 1-68

Townsend, D. W., Christensen, J. P., Stevenson, D. K., Graham, J. J., Chenoweth S. B. (1987b). The importance of a plume of tidally-mixed water to the biological oceanography of the Gulf of Maine. J. mar. Res. 45: $699-728$

Manuscript first received: June 15, 1988

Revised version accepted: March 16, 1989 